\title{
Objective Clinical Change of Cognitive-Behavioral Strategies for Binge Eating Behavior: Case Report
}

\section{María Leticia Bautista-Díaz ${ }^{1}$ (D), Diana J. Bernardino-Miranda1 (ํ), Mayaro Ortega-Luyando1 ${ }^{(0)}$, Adriana Amaya-Hernández 1 (D), Karina Franco-Paredes ${ }^{2} \mathbb{( D )}$}

\author{
${ }^{1}$ Facultad de Estudios Superiores Iztacala, Universidad Nacional Autónoma de México, Mexico City, Mexico \\ ${ }^{2}$ Centro de Investigación en Riesgos y Calidad de Vida, Universidad de Guadalajara, Jalisco, Mexico \\ Email:psile_7@yahoo.com.mx, jhosebetbm@gmail.com,psic.mayaro@gmail.com, \\ adriana.amaya@iztacala.unam.mx,karina.franco@cusur.udg.mx
}

How to cite this paper: Bautista-Díaz, M. L., Bernardino-Miranda, D. J., Ortega-Luyando, M., Amaya-Hernández, A., \& Franco-Paredes, K. (2020). Objective Clinical Change of Cognitive-Behavioral Strategies for Binge Eating Behavior: Case Report. Psychology, 11, 1876-1889.

https://doi.org/10.4236/psych.2020.1112119

Received: November 4, 2020

Accepted: December 19, 2020

Published: December 22, 2020

Copyright $\odot 2020$ by author(s) and Scientific Research Publishing Inc.

This work is licensed under the Creative Commons Attribution International License (CC BY 4.0).

http://creativecommons.org/licenses/by/4.0/

\begin{abstract}
The binge eating behavior in addition to affecting physical health generates psychological discomfort. The aim of this research was to evaluate the objective clinical change of an intervention with cognitive-behavioral strategies to modify binge eating and its associated variables. In this case report, two women (19 and 20 years old, respectively) diagnosed with binge eating disorder took part who signed an informed consent form and answered a battery of validated questionnaires in the Mexican population, this in the Pretest and Posttest phases to assess binge eating, body dissatisfaction, self-esteem, anxiety and depression symptoms, and quality of life. It was found that through the calculation of the objective clinical change, a favorable change between $50 \%$ and $80 \%$ of the assessed variables was found. It is concluded that the intervention using cognitive-behavioral strategies had a positive effect on binge eating and its associated variables. However, due to the nature of the study, it is not meant to generalize the findings, a case-control study would be necessary to strengthen these data to the medium and long term.
\end{abstract}

\section{Keywords}

Quality of Life, Body Image, Anxiety, Self-Esteem, Binge Eating, Obesity

\section{Introduction}

The world today and Mexico in particular, experience a high prevalence of obesity. According to the preliminary results of the Mexican National Health and Nutrition Survey (ENSANUT-2018; Instituto Nacional de Salud Pública [Mex- 
ico's National Institute of Public Health, 2018]) which show a rising trend over the years, $74.9 \%$ of the Mexican population $>20$ years old $(74.9 \%$ of women and $71.2 \%$ of men) are overweight or obese people. One of the universally used indicators in the clinical research field to determine excess weight is the body mass index (BMI), since it is an inexpensive and easy-to-perform method. The BMI is calculated by dividing a person's weight in kilograms by the square of his or her height in meters. If a BMI is $\geq 30$, it falls within the obesity range; frequently subdivided into categories: Class 1: BMI of 30.0 to 34.9; Class 2: BMI of 35.0 to 39.9 and Class 3: BMI equal or greater than 40.0 (World Health Organization [WHO], 2020). A high BMI is a risk factor for the development of comorbid conditions associated with a more complex clinical management and treatment.

It is known that genetic, environmental or psychological factors are involved in the etiology of obesity. However, there is more scientific evidence for environmental factors such as consumption of high energy/high fat foods, sugary beverage intake, little or no physical activity, (sedentary lifestyle); while for psychological factors, have been related to eating disorders (ED), specifically the binge eating disorder (BED; Morales et al., 2015). Almost 50\% of obese patients have binge eating episodes and one fifth (20\%) suffer BED (Castro \& Ramírez, 2013). For two last decades, BED has been deemed the most common eating disorder (DSM-5, American Psychiatric Association [APA], 2013). Likewise, this psychopathology has been associated with body dissatisfaction (Cuadro \& Baile, 2015; Naumann, Svaldi, Wyschka, Heinrichs, \& von Dawans, 2018; López-Aguilar, Vázquez-Arévalo, Mancilla-Díaz, Ocampo, \& Alvarez-Rayón, 2017), low self-esteem y depression (Morales et al., 2015); anxiety (Gómez-Alva et al., 2017) and an inappropriate quality of life (Cuadro \& Baile, 2015).

BED's main criterion is the binge eating characterized by the consumption of unusually large amounts of food once a week for less than a 2-hour period with a three-month recurrence duration. BED is also characterized by a loss of control over the foods consumed consisting of eating at a faster speed than normal without experiencing true physiological hunger. In addition, after a binge eating episode, there is an important feeling of guilt among other feelings such as depression, shame or disgust. All the foregoing put a BED patient's overall health at risk (DSM-5, APA, 2013).

Some BED treatments focus on weight loss (Katz et al., 2017), but it observed a rebound effect, gaining back all of the lost weight within the following year (Aguilar et al., 2015). Hence, a BED treatment must mainly address the eating psychopathology and not the excess weight condition; about this, treatments including self-regulation of eating behavior have been proposed (Katz et al., 2017).

Treatments for binge eating or BED can be: 1) pharmacological with antidepressants or appetite suppressants, despite some negative consequences which prove their effectiveness in the short-term only (Cuadro \& Baile, 2015); 2) psychological treatments aimed at achieving a psychological adjustment, modifying the cause of the psychopathology to avoid complications and prevent relapses, 
therefore, the only post-treatment outcome should be sustained re-learning in favor of psychological health. In this regard, ample effectiveness of the cognitive-behavioral therapy (CBT) has been proven equally for ED (Johnsen \& Friborg, 2015). Furthermore, there is specific evidence of the positive effect of such therapy for BED, as well as the suggestion that results are enhanced when therapy is individual (Cuadro \& Baile, 2015).

In this regard, despite the effectiveness of Self-Help CBT (Fairburn, 2017), patients are at a high risk of interrupting the treatment because self psycho-education requires a very high motivation; whereas considering $3^{\text {rd }}$ generation $\mathrm{CBT}$ techniques have still produced weak results (Iacovino, Gredysa, Altamn, \& Wukfkey, 2012), this being the case and with the pursuit of offering a different format to treat binge eating and BED with simple cognitive and behavioral strategies, as well as an analysis beyond descriptiveness, the aim of this research was evaluating the objective clinical change of an intervention with cognitive-behavioral strategies to modify binge eating behavior and its associated variables.

\section{Patients Identification and History of Problem}

Participants requested support to eating behavior laboratory of University to treat their eating behavior because it was affecting their psychological well-being (e.g., feelings of sadness, worry, low self-concept), which became reason for inquiry. Participant 1 (hereinafter referred to as Pa1), 19-year-old university student, with a body weight of $97.8 \mathrm{~kg}$ and a 40.2 BMI. Participant 2 (hereinafter referred to as Pa2), 20-year-old with a body weight of $101.2 \mathrm{~kg}$. Through the interview for Eating Disorder Diagnosis IV (IDED-IV; Kutlesic, Williamson, Gleaves, Barbin, \& Murphy-Eberenz, 1998) and a 24-hour food reminder, a specialist diagnosed both participants with BED, based on DSM-5 criteria (APA, 2013). In general, the participants stated that in the last year, they had had four (Pa1) and three (Pa2) binge eating episodes per week respectively, in other words, they ate unusually large amounts of food compared to what any person could possibly eat under the same circumstances, experiencing a loss of control as well as hiding to eat until they felt unpleasantly stuffed, in addition to the fact that they both fasted on an irregular basis as a compensatory behavior. According to the frequency of binge eating episodes, $\mathrm{Pa} 1$ is identified as moderately severe and $\mathrm{Pa} 2$ as mildly severe BED.

\section{Selection of Adequate Treatment and Establishment of Therapeutic Goals}

The authors based on the participants characteristics, decided to design an intervention program with cognitive-behavioral strategies to modify binge eating and associated variables with an experimental design. In an ad hoc plan, the protocol and its procedure were explained to them and they accepted participating in study and signed the informed consent form, which is based on The Code of Ethics for Psychologists (Sociedad Mexicana de Psicología [Mexican Psychology Association], 2010), section on Quality of Psychological Interven- 
tions (Articles 29 - 36), protecting participants from any physical or psychological dangers at all times, as well as from discomfort during intervention, and adhered to the Helsinki declaration for research with human beings (Asociación Médica Mundial [World Medical Association], 2013). Risk Classification: this study did not use invasive methods of any kind, nor techniques that put the physical integrity of the participants at risk, therefore, according to article 17 bis, section I of the regulations of the General Health Law regarding research for health, it is classified as research with minimal risk (Gobierno de México [Government of Mexico], 2018).

\subsection{Phases of the Intervention Program}

Phase I. Pretest (four weeks before the intervention): which was conducted in two sessions: 1) Signing of informed consent form (ICF), filling out the personal information page and the battery of questionnaires; 2) Registration of body measurements; Phase II. Design of an intervention program to modify the binge which was ruled by expert judges in eating behavior. Phase III. Intervention program implementation (comprised by 14 sessions). Phase IV. Posttest (two months after of the intervention), performed in two sessions: 1) Battery of questionnaires as Pretest phase; 2) diagnostic interview.

\subsection{Measures}

In the Pretest and the Posttest phases as well, the participants answered a battery of questionnaires to measure the following dependent variables:

Binge eating. Binge Eating Subscale of Bulimia Test (BULIT; Smith \& Thelen, 1984), which consists of 11 questions with Likert-type response options (11 - 55 scores), higher scores, greater presence of the assessed trait. This subscale has an Alpha coefficient of 0.85 , for the Mexican population (Alvarez, Mancilla, \& Vázquez, 2000).

Body Dissatisfaction. Body Image Questionnaire (BSQ). Designed by Cooper, Taylor, Cooper, \& Fairburn (1987). Adapted and validated for the Mexican population by Vázquez et al. (2011), who report an excellent internal consistency $($ Alpha $=0.98)$ and propose a cut-off point $(\mathrm{CP})=110$, as a clinically relevant body dissatisfaction indicator.

Self-Esteem. Rosenberg Self Esteem Scale (RSES). Developed by Rosenberg (1965) with the aim of assessing an individual's global self-worth perception (self-respect and self-acceptance). The original scale consists of 10 questions (Likert-type response options), but through a Confirmatory Factor Analysis (Jurado, Jurado, López, \& Querevalú, 2015), excluded two questions for the Mexican population (Alpha $=0.79)$ and the following cut-off point: $1-25$ low; $26-28$ moderate; 29 - 30 adequate; 31 - 32 very high self-esteem.

Depression symptoms. Beck Depression Inventory (BDI). Designed by Beck, Ward, Mendelson, Mock, and Erbaugh (1961) to measure the severity of depression symptoms based on 21 phrases, each one with four response options. Jura- 
do et al. (1998) examined their internal consistency (Alpha $=0.87)$ in the Mexican population and, as to their standardization, suggested the following four levels to designate the intensity of depression symptoms: 0 - 9 minimal, $10-16$ mild, 17 - 29 moderate, and 30 - 63 severe.

Anxiety symptoms. Beck Anxiety Inventory (BAI). Developed by Beck, Epstein, Brown, and Steer (1988) to assess the severity of symptomatic and behavioral anxiety categories; Robles, Varela, Jurado and Páez (2001) assessed their psychometric properties in the Mexican population and reported good internal consistency (Alpha $=0.83$ ), based on scores, these authors suggest the following classification: 0 - 5 minimal, 6 - 15 mild, 16 - 30 moderate, y 31 - 63 severe.

Quality of life. Brief version of the Quality of Life Questionnaire of the World Health Organization (WHOQOL-Bref; Harper \& Power, 1998) which consists of 26 questions structured in four dimensions: Physical Health, Psychological Well-Being, Social Relationships and Environment. Each item has five Likert-type response options which are converted in a score range from 0 to 100 , a higher score, indicates a better quality of life. The questionnaire is sufficiently reliable (Alpha $=0.75$; González-Celis, Tron, \& Chávez, 2009). Despite the fact this questionnaire does not have a $\mathrm{CP}$, it has a reference value for patients that attend health clinics ( $\leq 50)$ as an indicator of an inappropriate quality of life (GonzálezCelis, 2002).

\subsection{Practical Application of the Treatment Strategies}

Into the installations of a university laboratory of eating behavior was applied the intervention, program based on cognitive-behavioral techniques and strategies which consists of 14 sessions ( 2 per week, 60 minutes per session). The areas are 1) psychoeducation for eating behavior and body dissatisfaction; 2) training to identify conditions, circumstances, consequences and maintainers of binge eating behavior; 3) training for the development of behavioral objectives; 4) identification of beliefs and congruent/incongruent behavior; 5) self-questioning.

\section{Results: Evaluation of the Effectiveness of the Intervention}

1) Descriptive terms based on total scores both in the pre-test and post-test phases, to characterize the sample.

2) Objective clinical change (OCC) was calculated using the formula proposed by Cardiel (1994), which stipulates that $a \geq 20$ value is a significant change indicator to show or not a positive effect after intervention.

3) Personalized analysis of the two participants.

\subsection{Pretest Assessment}

In Table 1, data such as weight, BMI and scores of the battery of questionnaires in the Pre-Test Phase, can be observed. Taking the BMI values into consideration, as it can be seen, $\mathrm{Pa} 1$ is considered morbidly obese (Class III) and $\mathrm{Pa} 2$ with Class II obesity, the values of this index indicate that their health was at a 
Table 1. Body and psychological scores of the participants in the prestest phase.

\begin{tabular}{ccc}
\hline Variable & \multicolumn{2}{c}{ Participant } \\
\cline { 2 - 3 } Weight & 1 & 2 \\
Body mass index & Score & \\
Binge eating & $97.8 \mathrm{~kg}$ & $101.2 \mathrm{~kg}$ \\
\hline Total Body Image Questionnaire & 40.2 & 36.2 \\
Total Rosenberg Self-Esteem Scale & 44 & 47 \\
Total Beck Depression Inventory & 170 & 161 \\
Total Beck Anxiety Inventory & 20 & 28 \\
Total Quality of Life Questionnaire & 15 & 18 \\
Physical health & 36 & 20 \\
Psychological health & 40 & 43 \\
Social relationships & 38 & 44 \\
Environment & 44 & 44 \\
\hline
\end{tabular}

Note: Own search data.

higher risk, in other words, this body condition could contribute to develop or maintain medical or psychological obesity-related comorbidities.

Regarding the dependent variables, it is observed that both participants were above the median binge eating subscale $(\mathrm{Me}=33)$ scores; moreover, they exceeded the BSQ CP $\geq 110$; as for self-esteem, Pa1 had a low self-esteem and Pa2's self-esteem was moderate; regarding depression symptoms, these were mild for $\mathrm{Pa} 1$ and moderate for Pa2; whereas anxiety symptoms were severe for Pa1 and moderate for Pa2. As for total quality of life and its dimensions, these were below the reference value for the Mexican population in relation to the WHOQOL-Bref, except Environment for Pa2.

Findings provided evidence indicating that the psychological health (See Table 1) of the two participants with BED was affected (Pretest Phase).

\subsection{Pretest and Posttest Assessment}

Participant' scores of three of the assessed variables between the Pretest and Posttest phases are shown in Figure 1. As it can be seen with the subscale BULIT (binge eating), Pa1 went down 14-points, whereas Pa2 went down 16-points in the Posttest phase. As for body dissatisfaction which was assessed with the BSQ, it can be observed that Pa1 went down 82-points and Pa2, 50-points. Whereas higher scores for self-esteem assessed with the RSES can be observed, Pal went up 4-points and $\mathrm{Pa} 2$, 1-point.

In Figure 2, the scores of the two mood variables of the Pretest and Posttest phases can be observed. Regarding depression symptoms which were assessed 


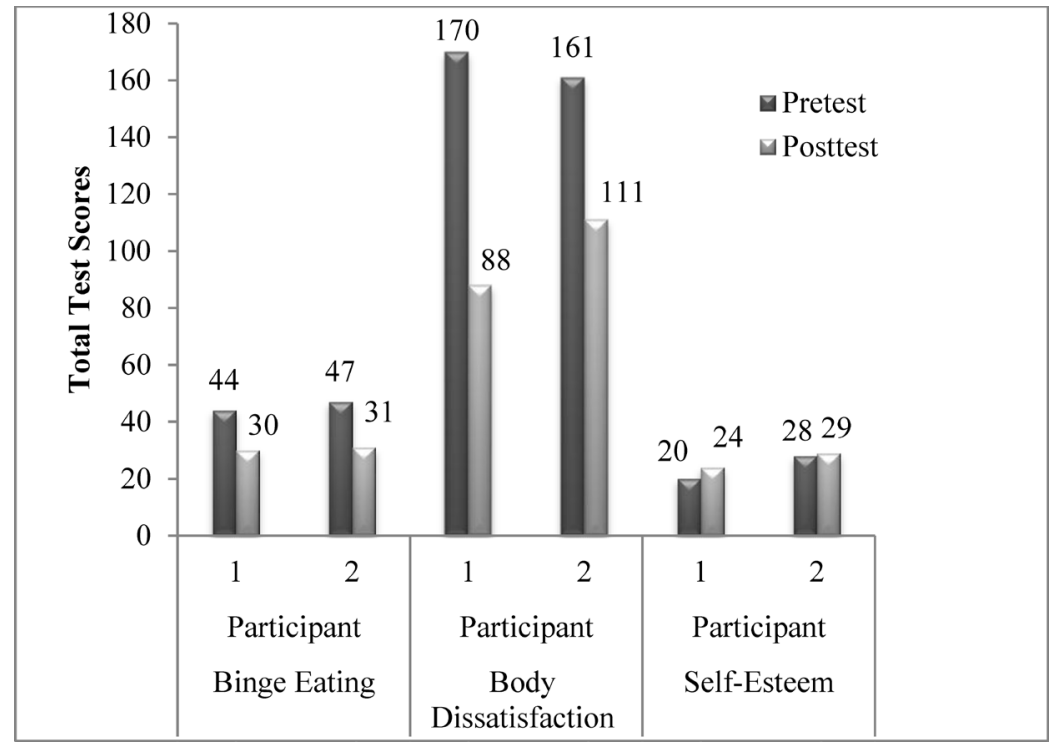

Figure 1. Participant scores regarding to binge eating, body dissatisfaction and self-esteem in Pretest and Posttest phases. Source: own research data.

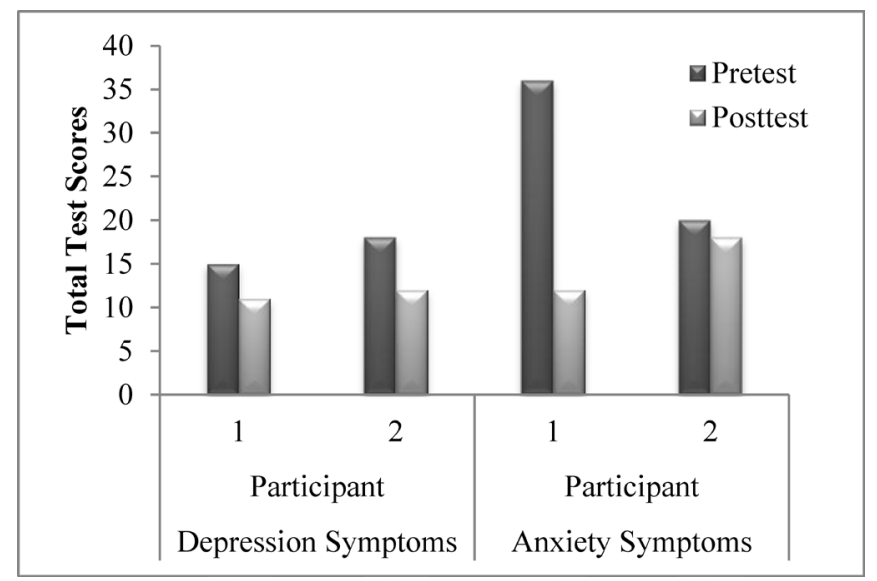

Figure 2. Participant scores regarding to depression and anxiety symptoms in Pretest and Posttest phases. Source: own research data.

with the BDI, in Pa1 a 4-point drop can be seen and 6-points in Pa2. As for anxiety symptoms assessed with the BAI, Pa1 went down 24-points and Pa2, 2-points.

However, in relation to total quality of life and its four dimensions assessed with the WHOQOL-Bref, in Figure 3, we can observe the scores and compare them with the $\leq 50$ reference value, in which it can be seen that in the Pretest phase most dimensions were below said value, except for Environment in Pa2's case (Sample question: How often do you have a chance to participate in recreational activities?), considering that it is reported as appropriate in both the pretest and posttest phases. The rise in the Physical Health dimension of both participants stands out (Sample question: How much energy do you have for your everyday life?), as well as Pal's psychological health (Sample question: Do you feel satisfied with your life?). 


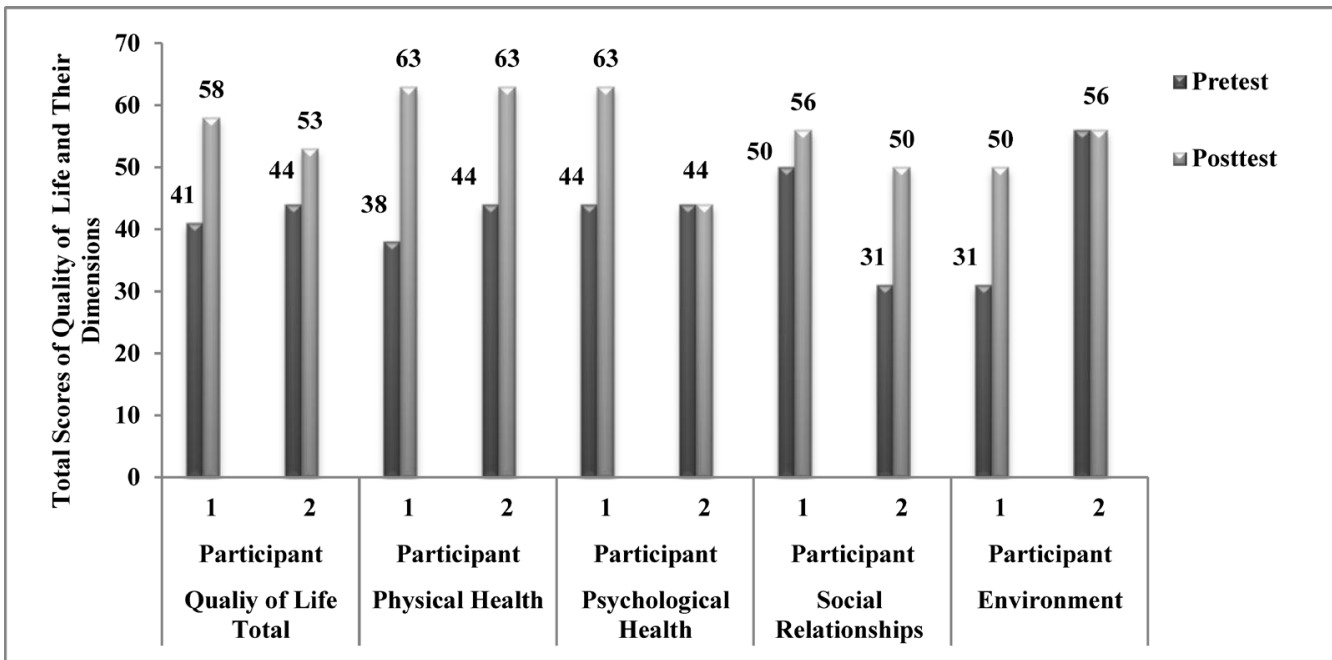

Figure 3. Participants' scores regarding to quality of life and their dimensions in Pretest and Posttest phases. Source: own research data.

\subsection{Objective Clinical Change after the Intervention}

On the other hand, with the purpose of assessing the OCC (between the Pretest and Posttest phases), the formula proposed by Cardiel (1994) was used and the results can be seen in Table 2. In Pal's case-in 10 of the assessed variables-an OCC was observed in eight (80\%; binge eating, body dissatisfaction, anxiety symptoms, total quality of life, physical and psychological health and environment) and did not any change in $20 \%$ of variables (depression symptoms and social relationships); whereas $\mathrm{Pa} 2$ showed OCC in five variables (50\%; binge eating, body dissatisfaction, total quality of life, physical health and social relationships), and did not show any OCC in self-esteem, depression and anxiety symptoms and remained stable in psychological health and environment.

\subsection{Personalized Analysis of the Two Participants}

Finally, when performing a more personalized analysis, the participants reported a decrease in their binge eating frequency: Pa1, from 4 to 0 and Pa2, from 3 to 0 . Nevertheless, attention is drawn to the fact that when taking the 3-month duration criterion for BED symptoms into consideration according to the DSM-5 (APA, 2013), the participants continued meeting the diagnosis criterion, despite the drop in the frequency of the number of binge eating episodes, given that the criterion is three months and at the time of the post-assessment, two months and 3 weeks had gone by. However, during and at the end of the intervention, both participants reported a momentary and general feeling of well-being, since they did not gain weight and were able to achieve the eating behavior objectives.

Considering the elements of intervention regarding the development of behavioral goals (specific and measurable in terms of behavior), the following examples of same is presented herein: Pal "I will establish specific times to eat my meals with alerts on my cell phone". Pa2 "Pll eat less chocolates and keep a record". 
Table 2. Objective clinical change in relation to the assessed variables.

\begin{tabular}{|c|c|c|c|}
\hline Variable & Participant & $\begin{array}{l}\text { Percentage of objective } \\
\text { clinical change }(\geq 20 \%)\end{array}$ & Change status \\
\hline \multirow{2}{*}{ Binge eating } & 1 & 29 & Yes \\
\hline & 2 & 30 & Yes \\
\hline \multirow{2}{*}{ Body dissatisfaction } & 1 & 87 & Yes \\
\hline & 2 & 31 & Yes \\
\hline \multirow{2}{*}{ Self-Esteem } & 1 & 23 & Yes \\
\hline & 2 & 3 & Not \\
\hline \multirow{2}{*}{ Depression symptoms } & 1 & 14 & Not \\
\hline & 2 & 17.4 & Not \\
\hline \multirow{2}{*}{ Anxiety symptoms } & 1 & 35.7 & Yes \\
\hline & 2 & 19.1 & Not \\
\hline \multirow{2}{*}{ Quality of life Total } & 1 & 57 & Yes \\
\hline & 2 & 52 & Yes \\
\hline \multirow{2}{*}{ Physical health } & 1 & 65 & Yes \\
\hline & 2 & 43 & Yes \\
\hline \multirow{2}{*}{ Psychological health } & 1 & 43 & Yes \\
\hline & 2 & - & Stable \\
\hline \multirow[b]{2}{*}{ Social relationships } & 1 & 12 & Not \\
\hline & 2 & 61 & Yes \\
\hline \multirow{2}{*}{ Environment } & 1 & 61 & Yes \\
\hline & 2 & - & Stable \\
\hline
\end{tabular}

Note: Own search data.

As for identification of incongruent beliefs: Pa1 said "...I can't always eat healthy food or give myself time ..."; Pa2 said, "Pll go to the store and buy everything I see", this type of thoughts are conducive to incongruent behaviors and therefore, self-questioning helped them modify incongruent beliefs and achieve objectives.

Now, regarding the identification of conditions that trigger binge eating episodes, an example of each participant is provided herein: Pa1, “...It was about 6 p.m. and I was alone. I felt anxious and decided to open the refrigerator and look for something to eat. I thought that I would only eat a little, but started binging, however, I realized what was happening and stopped eating...". The participant mentioned that she felt happy for being able to stop the binge eating episode, and at the same time she experienced a pleasant sensation with what was happening; Pa2, “...It was 9 p.m., I was in my bedroom and a family argument made me feel angry and desperate. My first thought was to eat something, and I went out to buy three bags of potato chips and an energy drink. When I got back home, I locked myself up and started eating, but when self-questioning my feel- 
ings, hunger vs. anger, I stopped eating and this calmed me down and I felt happy".

\section{Discussion}

The general aim of this research was evaluating the objective clinical change of an intervention with cognitive-behavioral strategies to modify binge eating behavior and its associated variables, which included psychoeducation on eating behavior and body dissatisfaction, training on identification of binge eating circumstances, consequences and maintainers, as well as training on development of behavioral objectives and identification of congruent and incongruent thoughts and behaviors associated with binge eating, as well as self-questioning.

Specifically, as for the intervention and regarding OCC which is deemed a more specific and individualized analysis, the findings herein reflect positive results in $80 \%$ and $50 \%$ of the assessed variables (binge eating episode, body dissatisfaction, self-esteem, depression/anxiety symptoms and quality of life) of the two participants, respectively. This data is similar to the data reported by García-Marín, Antón-Menárguez and Martínez-Amorós (2016) in an intervention with cognitive behavioral techniques (psychoeducation, breathing, stimulus control and self-instructions) with a participant with similar characteristics to the participants of this study, such as gender, age (19 years old), occupation (university student) and excess weight condition (morbid obesity) which documented a reduction of binge eating episodes, anxiety and depression symptoms an increased self-esteem.

Regarding body dissatisfaction, it is important to highlight that, although this is not a diagnostic criterion of BED, it affects patients with this eating psychopathology (Cuadro \& Baile, 2015; López-Aguilar et al., 2017; Naumann et al., 2018). In this regard, body dissatisfaction has been found to be a significant binge eating predictor (López-Aguilar et al., 2010), the scores reported by the participants of this study were way above Mexican population's CP and reduced substantially in the Posttest, specifically, one of the patients achieved an almost $90 \%$ of positive change. These findings show that a reduction of this characteristic in patients with BED is possible and contributes to their psychological health, considering that body dissatisfaction may work as a trigger or maintainer of a binge eating episode.

As for quality of life and its dimensions, a moderate improvement was found in this construct, similar results were reported in a meta-analysis, both for quality of life in general as well as life related to health. It was further indicated that findings were better in individual interventions (Linardon \& Brennan, 2017). Recently, linear relationship between BED and quality of life was not found because depression moderates this relationship (Singleton, Kenny, Hllet, \& Carter, 2019). In this study after the intervention, an increase in the quality of life was observed.

The psychological treatment is a professional intervention aimed at develop- 
ing adequate skills to cope with different alterations, both psychopathological as well as non-psychopathological and under this logic, the participants of this study, achieved learning the design as well as achievement of the behavioral objectives, identification of beliefs and incongruent behaviors, as well as the identification of conditions that trigger binge eating episodes and their self-questioning.

There is documentary evidence that CBT, its techniques and strategies are based on scientific evidence and therefore have yielded positive results for psychological alterations in general, and for ED, specifically for BED (de Jong, Schoorl, \& Hoek, 2018); this study adds to said results.

\section{Conclusion}

The objective clinical change allows to conclude that this intervention based on cognitive and behavioral strategies had a positive effect on the frequency of the binge eating behavior, as well as a reduction of body dissatisfaction, increase of self-esteem, reduction of anxiety symptoms and a moderate improvement in the participants' quality of life which consequently lead to a momentary and general well-being. Psychopathologies are complex health issues, due to which treating same requires an interdisciplinary team, therefore, these findings could benefit from the contributions of other health disciplines, so that, instead of performing a secondary prevention, a primary prevention is performed. Accordingly, in obesity and BED cases, an intervention mainly focused on the eating psychopathology aside from simultaneous treatment of obesity is necessary. These results enable us to hypothesize that, the development of-specific and achievable behavioral objectives in the short term-and the identification of congruent and incongruent beliefs and behaviors, as well as the identification of conditions that trigger binge eating episodes and self-questioning, may also be the basis for universal, primary prevention in $\mathrm{ED}$, notwithstanding the fact that behavioral records could be included to analyze specific behaviors.

The results of this study are not meant to generalize, considering that the participants in this intervention have certain characteristics and the program must be tried on participants with different characteristics (e.g., age, gender and level of education). What is clear is that changes were not generated randomly and correspond to a specific methodology which may be susceptible to replication. However, in future research, broad samples of cases and controls and mediumand long-term assessments must be used to assess learning throughout time.

\section{Conflicts of Interest}

The authors declare no conflicts of interest regarding the publication of this paper.

\section{References}

Aguilar, M. J., Ortegón, A., Baena, L., Noack, J. P., Levet, M. C., \& Sánchez, A. M. (2015). Efecto Rebote de los Programas de Intervención para Reducir el Sobrepeso y la Obesidad de niños y Adolescentes; Revisión Sistemática. Nutrición Hospitalaria, 32, 
2508-2517.

Alvarez, G., Mancilla, J. M., \& Vázquez, R. (2000). Propiedades Psicométricas del Test de Bulimia (BULIT). Psicología Contemporánea, 7, 74-85.

American Psychiatric Association, APA (2013). Diagnostic and Statistical Manual of Mental Disorders (5th ed.). Washington DC: American Phychiatric Association. https://doi.org/10.1176/appi.books.9780890425596

Asociación Médica Mundial (2013). Declaración de Helsinki de la AMM. http://www.conbioetica-mexico.salud.gob.mx/descargas/pdf/Declaracion_Helsinki_Bra sil.pdf

Beck, A., Epstein, N., Brown, G., \& Steer, R. (1988). An Inventory for Measuring Clinical Anxiety: Psychometric Properties. Journal of Consulting and Clinical Psychology, 56, 893-897. https://doi.org/10.1037/0022-006X.56.6.893

Beck, A., Ward, C., Mendelson, M., Mock, J., \& Erbaugh, J. (1961). An Inventory for Measuring Depression. Archives of General Psychiatry, 4, 561-567.

https://doi.org/10.1001/archpsyc.1961.01710120031004

Cardiel, R. M. (1994). La Medición de la Calidad de Vida. In L. Moreno, F. Cano-Valle y H. García-Romero (Eds.), Epidemiología Clínica (pp. 189-199). México: Interamericana-McGraw Hill.

Castro, A. L. \& Ramírez, A. L. (2013). Prevalencia de Manifestaciones del Trastorno por Atracón en Adultos con Sobrepeso y Obesidad, Costa Rica. Revista Costarricense de Salud Pública, 22, 20-26. https://www.scielo.sa.cr/pdf/rcsp/v22n1/art05v22n1.pdf

Cooper, P. J., Taylor, M. J., Cooper, Z. \& Fairburn, C. G. (1987). The Development and Validation of the Body Shape Questionnaire. International Journal of Eating Disorders, 6, 485-494.

https://doi.org/10.1002/1098-108X(198707)6:4<485::AID-EAT2260060405>3.0.CO;2-O

Cuadro, E., \& Baile, J. I. (2015). Binge Eating Disorder: Analysis and Treatment. Revista Mexicana de Trastornos Alimentarios, 6, 97-107.

de Jong, M., Schoorl, M., \& Hoek, H. (2018). Enhanced Cognitive Behavioural Therapy for Patients with Eating Disorders: A Systematic Review. Current Opinion of Psychiatry, 31, 436-444. https://doi.org/10.1097/YCO.0000000000000452

Fairburn, C. (2017). La Superación de los Atracones de Comida. Cómo Recuperar el Control (1st ed.). Barcelona: Paidós.

García-Marín, O., Antón-Menárguez, V., \& Martínez-Amorós, R. (2016). Tratamiento Cognitivo-Conductual de un Trastorno por Atracón en una Adolescente Tardía con Obesidad Mórbida. Revista de Psicología Clínica con Niños y Adolescentes, 3, 67-74.

https://www.revistapcna.com/sites/default/files/garcia-marin_et_al_2016_tcc_trastorno _por_atracon.pdf

Gobierno de México (2018). Ley General de Salud. http://www.ordenjuridico.gob.mx/Documentos/Federal/pdf/wo11037.pdf

Gómez-Alva, A., Fernández-Murillo, Velásquez-Fernández, D., Flores-Morales, J., León, P., Mercado-Celis, G. E., Herrera-Hernández, M. F. et al. (2017). Trastorno por Atracón, Depresión, Ansiedad y gen del Neuropéptido Relacionado con Agouti en Pacientes con Cirugía Bariátrica. Revista Mexicana de Trastornos Alimentarios, 8, 161-170.

González-Celis, A. L. (2002). Efectos de la Intervención en un Programa de Promoción de la Salud Sobre la calidad de Vida en Ancianos. Tesis de Doctorado Inédita, México: Universidad Nacional Autónoma de México.

González-Celis, A. L., Tron, R., \& Chávez, M. (2009). Evaluación de la Calidad de Vida: A 
Través del WHOQOL en Población de Adultos Mayores en México. Master's Thesis, México: Universidad Nacional Autónoma de México.

Harper, A., \& Power, M. (1998). Development of the World Health Organization WHOQOL-BREF Quality of Life Assessment. Psychological Medicine, 28, 551-558. https://doi.org/10.1017/S0033291798006667

Iacovino, J., Gredysa, D., Altman, M., \& Wilfley, D. (2012). Psychological Treatments for Binge Eating Disorder. Current Psychiatric Reports, 14, 432-446. https://doi.org/10.1007/s11920-012-0277-8

Instituto Nacional de Salud Pública (2018). Encuesta Nacional de Salud y Nutrición 2018. Presentación de Resultados.

https://ensanut.insp.mx/encuestas/ensanut2018/doctos/informes/ensanut_2018_presen tacion_resultados.pdf

Johnsen, T. J., \& Friborg, O. (2015). The Effects of Cognitive Behavioral Therapy as an Anti-Depressive Treatment Is Falling: A Meta-Analysis. Psychological Bulletin, 142, 747-768.

Jurado, D., Jurado, S., López, K., \& Querevalú, B. (2015). Validez de la Escala de Autoestima de Rosenberg en Universitarios de la Ciudad de México. Revista Latinoamericana de Medicina Conductual, 5, 18-22.

https://www.redalyc.org/pdf/2830/283046027004.pdf

Jurado, S., Villegas, M., Méndez, L., Rodríguez, F., Loperena, V., \& Varela, R. (1998). La Estandarización del Inventario de Depresión de Beck para Residentes Mexicanos. Salud Mental, 21, 26-31.

http://www.revistasaludmental.mx/index.php/salud_mental/article/view/706

Katz, M., Cppelletti, A., Ackeman, M., Paplia, L., Giannini, M., Viñuales, M. et al. (2017). Prevención de la ganancia de peso en adultos. Actualización en Nutrición, 18, 64-68. http://www.revistasan.org.ar/pdf_files/trabajos/vol_18/num_2/RSAN_18_2_64.pdf

Kutlesic, V., Williamson, D., Gleaves, D., Barbin, J., \& Murphy-Eberenz, K. (1998). The Interview for Diagnosis of Eating Disorders-IV: Application to DSM-IV Diagnostic Criteria. Psychological Assessment, 10, 41-48.

https://doi.org/10.1037/1040-3590.10.1.41

Linardon, J., \& Brennan, L. (2017). The Effects of Cognitive-Behavioral Therapy for Eating Disorders on Quality of Life. A Meta Analyses. International Journal of Eating Disorders, 50, 715-730. https://www.ncbi.nlm.nih.gov/pubmed/28430364 https://doi.org/10.1002/eat.22719

López-Aguilar, X. Vázquez-Arévalo, R., Mancilla-Díaz, J. M., Ocampo Téllez-Girón, M. T., \& Alvarez-Rayón, G. L. (2017). Restricción Alimentaria, Insatisfacción Corporal y Conductas Compensatorias en Obesas con Diferente Nivel de Patología Alimentaria (Atracón). Revista de Medicina, Psicosomática y Psiquiatría, 1, 14-23.

http://psicosomaticaypsiquiatria.com/wp-content/uploads/2017/09/psicosom_psiquiatr 201712_14_23.pdf

López-Aguilar, X., Mancilla-Díaz, J.M., Vázquez-Arévalo, R., Ocampo-Téllez-Girón, M.T., Franco-Paredes, K., \& Alvarez-Rayón, G.L. (2010). Factores Predictores del Atracón Alimentario en una Muestra Comunitaria de Mujeres Mexicanas. Journal of Behavior, Health \& Social Issues, 2, 25-38.

http://dx.doi.org/10.22201/fesi.20070780.2010.2.1.20407

Morales, A., Gómez, A., Jiménez, B., Jiménez, F., León, G., Majano, A. et al. (2015). Trastorno por Atracón: Prevalencia, Factores Asociados y Relación con la Obesidad en Adultos Jóvenes Universitarios. Revista Colombiana de Psiquiatría, 44, 177-182. https://doi.org/10.1016/j.rcp.2015.02.006 
Naumann, E., Svaldi, J., Wyschka, T., Heinrichs, M., \& von Dawans, B. (2018). Stress-Induced Body Dissatisfaction in Women with Binge Eating Disorder. Journal of Abnormal Psychology, 127, 548-558. https://doi.org/10.1037/abn0000371

Robles, R., Varela, R., Jurado, S., \& Páez, F. (2001). Versión Mexicana del Inventario de Ansiedad de Beck: Propiedades Psicométricas. Revista Mexicana de Psicología, 8, 211-217. https://scinapse.io/papers/1597953883

Rosenberg, M. (1965). Society and the Adolescent Self-Image. Princeton, NJ: Princeton University Press. https://doi.org/10.1515/9781400876136

Singleton, C., Kenny, T. Hallet, D., \& Carter, J. (2019). Depression Partially Mediates the Association between Binge Eating Disorder and Health-Related Quality of Life. Frontiers in Psychology, 10, 209. https://doi.org/10.3389/fpsyg.2019.00209

Smith, M. C. \& Thelen, M. H. (1984). Development and Validation of a Test for Bulimia. Journal of Consulting and Clinical Psychology, 52, 863-872. https://doi.org/10.1037/0022-006X.52.5.863

Sociedad Mexicana de Psicología (2010). Código ético del psicólogo. Normas de Conducta, Resultados de Trabajo y Relaciones Establecidas (5th ed.). México: Trillas.

Vázquez, R., Galán, J., López, X., Alvarez, G., Mancilla, J., Caballero, A., \& Unikel, C. (2011). Validez del Body Shape Questionnaire (BSQ) en Mujeres Mexicanas. Revista Mexicana de Trastornos Alimentarios, 1, 1-9.

http://www.scielo.org.mx/scielo.php?script=sci_arttext\&pid=S2007-15232011000100005

World Health Organization (2020). Obesity and Overweight.

https://www.who.int/es/news-room/fact-sheets/detail/obesity-and-overweight 